DOI https://doi.org/10.30525/978-9934-26-147-3-11

\title{
THE DEVELOPMENT OF THE TERRITORIES AS A COMPONENT OF COMPETITIVENESS OF STATE FORMATION UNDER THE CONDITIONS OF DECENTRALIZATION
}

\author{
Yasenchuk Yu. V. \\ Master of Program Subject Area 281 «Public Administration» \\ Vinnytsia Institute of Trade and Economics of Kyiv National University \\ of Trade and Economics \\ Vinnytsia, Ukraine
}

In modern times of state formation, it is attached great importance to local self-government. Despite the fact that in real practice established by legislative acts independence of regional government entities is not fully used yet, the experience of local authorities confirms the tendency to increase the functions they perform by delegating to lower levels a significant number of powers and management functions [1].

The development of the only concept of local self-government and its systemic constitutional and legal regulation in Ukraine is possible only if balanced combination of the best practices of functioning of this institution in democratic European countries, and also the fulfillment of Ukraine's commitments to implement the provisions of the European Charter of Local Self-Government in full and taking into account national traditions of state and legal development. In Ukraine, local self-government is recognized and guaranteed by the Constitution. Local self-government guarantees are one of the important principles stipulated in Article 4 of the Law of Ukraine «On Local Self-Government».

Today, Ukraine has set a course for decentralization and reform of the territorial organization of power. A key component of this reform is the optimization of the administrative and territorial structure of the state as a spatial basis for the functioning of government through the formation of voluntarily united territorial communities. As part of the conducted reforms, the state encourages the establishment of an institution of effective managers, including local government officials, and the association of active citizens who will be interested in using all possible legal means and measures to make their community effective.

It is important that in transition countries, decentralization reforms should be carried out in stages, so as not to disrupt coordination, without immediately delegating to local authorities the tasks they need to solve only in the longterm run. In addition, though the level of economic development of a country or region is determined to some extend by the possibilities of decentralization 42 
of power, in practice poor countries often tend to centralize. In other words, as the wealthier a country is, as the more responsibilities and resources it transfers to the places [5].

The state has identified a number of goals that pursue these reforms. Thus, at the state level, the reform should achieve the following goals:

1. strengthening the social and economic security of the state,

2. ensuring the social and economic growth of the state, regions, separate territories,

3. increasing the quality of life of citizens, regardless of place of living.

Local authorities face new challenges that require a deep understanding of the local development planning process, development and implementation of models and tools of local economic development, acquirement of the necessary knowledge, information, skills and experience to ensure more competitiveness of their territories in difficult global conditions. In line of scientific achievements in the direction of research of methodological bases of planning the development of territories it is highlighted the following types of planning:

- strategic planning, which outlines long-term objectives of the development of the territories based on the analysis of its potential ( 7 - 10 years);

- programs of social and economic development, which characterize the main directions of development of territories based on formed strategies of their development (1-2 years);

- projects to attract investment in the development of the territories (1-2 years).

Programming is part of the planning process, in which, guided by defined strategic and operational objectives, it is identified projects and activities that lead to the achievement of these objectives, and then similar projects and activities are grouped into appropriate programs.

Projects are interventions that have a clearly defined implementation period. The project is a logically and chronologically coordinated set of actions, the implementation of which leads to the achievement of a certain goal in fixed day, with the involvement of certain human, material and financial resources. The implementation of the project requires proper organization and definition of responsibilities.

Measures are direct interventions in one of the relevant areas of development. Unlike projects, they do not have well-defined deadlines and are usually repeated periodically. Measures often include relatively simple procedures, such as the introduction of a specific budget funding item (for example, co-financing of adult education activities) or the creation of a special body (for example, the Architecture and Construction Council).

Programs are the main tools for implementing development strategy. They integrate projects and activities that are interconnected in time and content. 
Projects and activities are joined into programs according to common logical features, which contribute to their better identification and facilitate management [3].

The local program of economic and social development is a document that defines the purpose, goals and priorities of economic and social development for the short term, usually for a year, means and ways to achieve them, forming a mutually agreed and comprehensive system of directions and measures of local governments directed on the effective solution of problems of economic and social development, characterized the expected changes in the state of the economy and social sphere [4].

Together with the program of social and economic development it is developed the local target programs which are its components. Such programs are aimed at solving local problems and are implemented within a definite part of the region (more precisely - within the association of a small number of villages, cities), therefore, in terms of regional governance, are classified as regional.

The accepted programs of social and economic development are documents of normative character, and that is why, by the decision of council it is possible to make changes and additions in them, moreover if necessary changes are also made to the local budget.

There are several methods of developing strategies of community development under the modern conditions of decentralization:

1. Method of paternalism. The strategy is developed by the government and municipal management, written in offices without any contact with the community.

2. Expert method. The strategy is developed by experts who do in-depth research of statistical indicators, use mathematical apparatus, conduct correlation or factor analysis, predict trends and propose action plans, professionally work on creating a strategy and faithfully work out the salary received.

3. Expert and advisory. The strategy is developed by experts who, in the process of researching the environment and developing the main directions of development, seek advice (round tables, public hearings, questionnaires, etc.) from the local community (business, public organizations, etc.) and government.

4. Administrative and advisory. The strategy is developed by the government and municipal management with the advisory involvement of the community through public opinion polls, round tables, public hearings, etc.

5. The method of «complicity», which is based on a long-term partnership with experts. The concept of the method is based on the collective participation of the community and the formation of a group of professionals from leaders of local communities, businesses and authorities, who work on the development strategy with the help of independent experts. 
Thus, the program of economic and social development is developed on the basis of a comprehensive analysis of the demographic situation, the state of use of natural, industrial, scientific, technical and labor potential, assessment of the achieved level of economic and social development, environmental assessment and the level of waste management.

It is necessary to take into account the influence of external, political, economic and other factors and the expected trends of change the influence of these factors in the future.

Consequently, the importance of forecasting and program documents of economic and social development should not be underestimated, as their indicators are a guide for business entities to develop their own forecasts, plans, business plans and other documents. Furthermore, such documents confirm the work of local authorities in defined areas, and therefore increase the efficiency of local governments, and the level of trust of local people in local government, and the probability of attracting additional resources to local development, including international technical assistance for certain planned activities and development projects.

\section{References:}

1. Bazylevych V.D., Popov V.M., Bazylevych K.S., Hrazhevska N.I. Economic theory: political economy: a textbook / ed. V.D. Bazylevych. 7th ed., Kyiv: Znannia-Press, 2008. 719 p.

2. Holovnina O.H. Fundamentals of social economy: a textbook. 2nd ed., Reworked. and add. Kyiv: Center for Educational Literature, 2013. 648 p.

3 . Ivanenko O. Formation of resource conservation potential of socioeconomic systems. Economics, finance, law. 2013. № 8. P. 7-10.

4. Ohanian H.A., Palamarchuk V.O., Rumiantsev A.P. Political Economy: Textbook. way. / ed. Ohanian H.A. Kyiv: Interregional Academy of Personnel Management, 2003. 520p.

5. Semenenko V.M., Kovalenko D.I., Buhas V.V., Semenenko O.V. Economic theory: Political Economy: textbook. way. / gen. ed. V.M. Semenenko and D.I. Kovalenko. Kyiv: Center for Educational Literature, 2010. 360 p. 